\title{
How can we improve information delivery to support conservation and restoration decisions?
}

\author{
Nathaniel E. Seavy $\cdot$ Christine A. Howell
}

Received: 31 December 2008/Accepted: 17 November 2009/Published online: 29 November 2009

(C) The Author(s) 2009. This article is published with open access at Springerlink.com

\begin{abstract}
Incorporating science into resource conservation and management is becoming increasingly important, but it is not yet clear how to provide information to decision makers most effectively. To evaluate sources of information used to support the management and conservation of California's riparian bird habitat, we distributed a questionnaire to restoration practitioners and public and private land managers. We asked respondents to rate the importance and availability of different sources of information they use to inform their decisions. Synthetic reviews and peer-reviewed publications both received high importance and availability ratings. Web-based tools received low importance and availability ratings. One-on-one interactions between ecologists and decision makers received high importance ratings, similar to those of peer-reviewed publications and synthetic reviews, but their availability was rated lower than any other method of decision support. Our results suggest that the decision makers we surveyed are already using a wide variety of information, but that prioritizing one-on-one interactions between scientists and decision makers will enhance the delivery of all sources of information.
\end{abstract}

Keywords Conservation planning · Decision support tools ·

Evidence-based conservation · Ecological restoration · Riparian

\section{Introduction}

Over the last 50 years, ecologists have generated an immense amount of knowledge about how natural systems work and how to protect and restore them. Just as modern science has

\footnotetext{
N. E. Seavy $(\bowtie) \cdot$ C. A. Howell

PRBO Conservation Science, 3820 Cypress Drive \#11, Petaluma, CA 94954, USA

e-mail: nseavy@prbo.org

C. A. Howell

e-mail: chowell@prbo.org

N. E. Seavy

Information Center for the Environment, Department of Environmental Science and Policy, University of California, Davis, CA 95616, USA
} 
revolutionized medicine, there is now an effort to shift the management of natural resources from an experience-based approach to an evidence-based approach (Pullin and Knight 2001; Salafsky et al. 2002). A major challenge in developing evidence-based management is identifying the most effective ways to incorporate scientific knowledge into the decision-making process (Pullin and Knight 2005; Pyke et al. 2007).

There are many sources of information that can help land managers and policy makers incorporate scientific evidence into the decision making process (Alexander et al. 2009). These sources include a wide variety of printed documents and computer-based sources of information that help decision makers understand how different choices will influence the natural resources they manage. In the peer-reviewed literature, papers that emphasize the management implications of ecological research can be used for decision support. Outside of the peer-reviewed literature, documents that synthesize large amounts of ecological information into a single resource are becoming more abundant. Examples of such documents include the habitat conservation plans developed by Partners in Flight (Bonney et al. 1999; Alexander et al. 2007), the systematic reviews prepared by the Center for Evidence-Based Conservation (Pullin and Stewart 2006), and "white papers" prepared to address specific management issues. There have also been efforts to provide decision support information in an interactive format, often available online, that allows managers to design and evaluate multiple alternative management scenarios or view spatially-explicit databases of previous management efforts or conservation priorities (Rauscher 1999; Twedt et al. 2006; Katz et al. 2007).

The conservation and restoration of riparian ecosystems illustrates many of the challenges of integrating ecological science with on-the-ground decisions. In North America alone, more than 1 billion dollars are now spent on riparian restoration each year (Bernhardt et al. 2005), but the degree to which these projects are informed by ecological science remains highly variable (O'Donnell and Galat 2008). Over the last two decades, PRBO Conservation Science (hereafter PRBO) has been involved with research designed to inform the conservation and restoration of riparian bird habitat in California. To communicate research results to land managers and policy makers, PRBO has worked to provide reports and peer-reviewed publications to land managers and participated in the development of synthetic reviews, such as the California Partners in Flight Riparian Habitat Conservation Plan (RHJV 2004).

In order to evaluate the importance and availability of information that PRBO provides for the management of California's riparian bird habitat, we distributed a questionnaire to restoration practitioners and public and private land managers. Here we report on the perceived importance and availability of five sources of information for decision makers. Our results have broader implications for improving the delivery of information designed to support decisions related to habitat conservation and restoration. This example may encourage other researchers interested in decision support to conduct similar efforts to understand the needs of their audiences.

\section{Methods}

With input from PRBO staff involved with riparian ecosystem research, outreach, and education, we designed a questionnaire to generate information about the importance and availability of sources of information used to support decisions associated with riparian habitat conservation and restoration in California. The questionnaire began with two questions that described the professional affiliation and responsibilities of the respondents. This was followed by a series of 24 topics, grouped into six categories, for which we asked 
Table 1 Five formats of information transfer and decision support for which respondents were asked to rate the importance and availability

\begin{tabular}{lc}
\hline Method described in questionnaire & Abbreviation \\
\hline $\begin{array}{l}\text { Peer-reviewed scientific publications in bird and ecology } \\
\text { journals (Condor, Conservation Biology, Restoration Ecology, etc.) }\end{array}$ & $\begin{array}{c}\text { Peer-reviewed } \\
\text { publications } \\
\text { Unpublished reports } \\
\text { Unpublished reports to management agencies }\end{array}$ \\
$\begin{array}{l}\text { Printed (also available on-line) sources that synthesize the result } \\
\text { of multiple studies (e.g., Cal PIF Riparian Habitat Conservation Plan, }\end{array}$ & Synthetic reviews \\
handouts, brochures, conservation plans) & \\
$\begin{array}{l}\text { Interactive web-based decision-support tools and information } \\
\text { Field trips, workshops, or one-on-one visits in which the developers } \\
\text { of decision-support information explain, discuss, and guide their } \\
\text { implementation }\end{array}$ & Web-based tools \\
\hline
\end{tabular}

The first column provides the word-for-word description of each method that was used in the questionnaire, the second column is the abbreviation used to refer to these methods in this manuscript

respondents to rate the importance and availability. A copy of the questionnaire is available upon request from the authors.

Both importance and availability ratings were based on a three-tiered categorical scale. For importance, the categories were low- "information rarely or never considered in your riparian projects", moderate- "information useful in only half of the riparian projects with which you are involved", or high- "information critical to every riparian project with which you are involved". Similarly, for availability the categories were low- "information is not available", moderate- "some information is already available, but more is needed", and high-"sufficient information is already available." We asked respondents to rate availability independent of the importance rating, such that even if a topic was of little importance to most projects, the availability would still be rated high if considerable information was available for this topic.

We distributed our survey in two ways. First, we solicited responses to a paper copy of the survey that was distributed during the poster session of the 2007 State of the Estuary meeting in Oakland, California and the 2008 Riparian Habitat Joint Venture meeting in Sacramento, California. We also designed an identical online version of the survey and sent out a request for responses to e-mail lists maintained by California Partners in Flight, the Western Chapter of The Wildlife Society, the San Francisco Bay Joint Venture, and the PRBO Conservation Science Restoration Group.

Here, we restrict our analysis to a single category "Information transfer and decision support", in which we asked respondents to rate the importance and availability of five methods of delivering information about the conservation and restoration of riparian bird habitat (Table 1). Three of these methods (synthetic reviews, peer-reviewed publications, and unpublished reports) were based on printed formats. The other two methods were interactive web-based tools and one-on-one interactions between the ecologists that develop decision support information and the decision makers who use this information.

\section{Results}

We received a total of 86 completed surveys, 19 paper copies from the meetings and 67 electronically. In the surveys we received, respondents identified their professional 
(A)

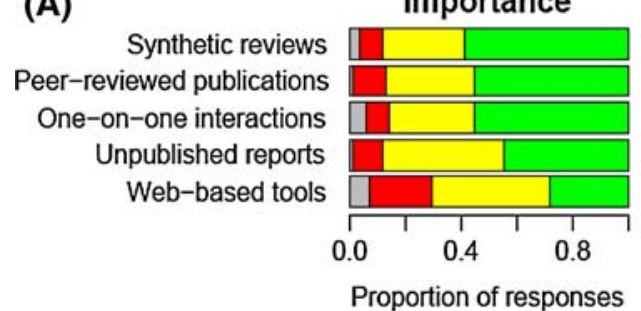

(B)

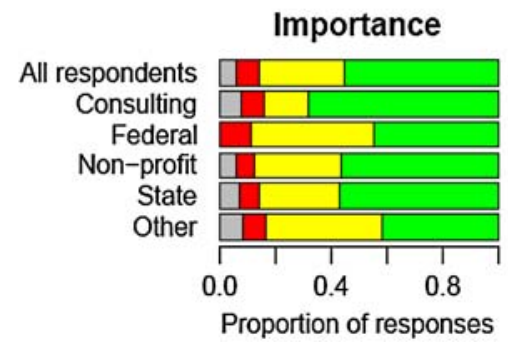

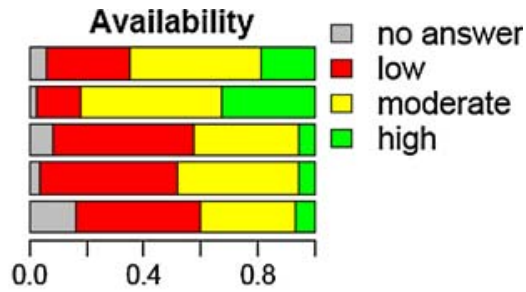

Proportion of responses

Availability

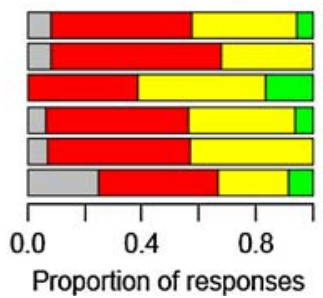

Fig. 1 Importance and availability ratings for a five types of information transfer and decision support as rated by all respondents, and $\mathbf{b}$ one-on-one interactions as rated by the five professional affiliations of the respondents

associations with environmental consulting firms (26 respondents), federal land or wildlife management (18 respondents), non-profit conservation or restoration organizations (16 respondents), state land or wildlife management (14 respondents), city or county land management (4 respondents), and other (8 respondents). Respondents that gave their professional affiliation as other included researchers, agriculture trade group representatives, Joint Venture coordinator, and utility and water agency representatives. Because the sample for city and county land managers was $<5$, we included them with the "other" category for all further analyses. The majority of respondents identified the decisions they make as involved with managing riparian habitat and designing riparian restoration. A lesser number made decisions related to awarding funds to riparian projects or selecting sites for restoration.

The importance and availability ratings varied among the five methods of providing information for decision support (Fig. 1). Synthetic reviews were ranked first in importance and second in availability. Peer-reviewed publications also had a high importance rating, and were rated as the most available method. Unpublished reports were moderately important, but they ranked much lower in their availability ratings. Web-based tools received low importance and availability ratings. In contrast, one-on-one interactions received relatively high importance ratings, similar to those of peer-reviewed publications and synthetic reviews. However, the availability of one-on-one interactions was rated lower than most other methods. Across respondents with different professional affiliations, one-on-one interactions consistently received high importance ratings, but much lower availability ratings (Fig. 1).

\section{Discussion}

As with all surveys that rely on non-random samples, the potential for self-selection bias is important to consider (Berk 1983). If the views of individuals that chose to respond to the 
survey were not representative of the entire sampling frame, then it would be inappropriate to generalize to the larger population. Thus, our results should be interpreted with caution. With this caveat in mind, we believe our results suggest three major points that ecologists should consider as they develop information to support decisions by land managers and policy makers.

Peer-reviewed publications and synthetic reviews are important and available

Often, one hears the statement that "managers don't have time to read the peer-reviewed literature." In contrast, our results suggest that peer-reviewed publications and synthetic reviews are perceived as an important component of riparian conservation and restoration decision making. On the surface, this result appears to contradict what previous studies have suggested-that these sources of information are used much less frequently by resource managers and restoration practitioners than are many less formal sources of information, such as personal experience (Pullin and Knight 2005; Kondolf et al. 2007). In part, this discrepancy may be explained by the fact that our questionnaire only asked about formal sources of information and did not evaluate their importance relative to other sources of information. Among sources of information we asked about, peer-reviewed publications and synthetic reviews were perceived as the most important and available (Fig. 1).

We suggest that ecologists should not underestimate the importance of publishing their results and contributing to conservation plans, white papers, and other printed materials that can guide habitat conservation and conservation. However, as the volume of this information grows, so does the need for well-organized clearinghouses that make this information available to a wide audience (Kondolf et al. 2007).

Web-based tools are not yet important or widely available

The relatively recent development of sophisticated, interactive web-based applications has introduced an entirely new medium for providing information to managers and policy makers. However, despite the enormous potential of these tools, our survey results suggest that for riparian habitat conservation in California, they are not yet perceived as important or available. We do not suggest that web-based tools should not be developed. Indeed, we agree that making information available on the internet will have many positive outcomes for conservation and restoration ecology (Jenkinson et al. 2005). However, our results suggest that simply making these tools available on the web will not be effective. To increase the utility of these tools, ecologists will need to engage with decision makers to provide the training they need to effectively use the tools.

Ultimately, the utility of online applications may not be that they provide a single tool, but that they provide managers with access to a dynamic collection of tools. Such "decision support systems" could be designed to provide managers with access to a library of electronic versions of traditional printed documents and site-specific data dynamically displayed with custom visualizations. In North America, the Avian Knowledge Network (http://www.avianknowledge.net) fosters the development of such systems through its distributed nodes, such as PRBO's California Avian Data Center (http://www.prbo.org/data) and Bird Study Canada's Nature Counts (http://www.birdscanada.org/birdmon/default/) (G. Ballard, pers. comm.). 
One-on-one interactions are important, but not available

Respondents from all professional affiliations agreed that one-on-one interactions with ecologists who develop information to support decisions are important, but not widely available (Fig. 1). This result supports the conclusion that collaboration between managers and scientists, not just more published studies, are needed to improve the practice of river restoration (Bernhardt et al. 2007). To provide effective decision support ecologists need to do more than simply provide a paragraph describing the "management implications" at the conclusion of peer-reviewed manuscripts; they must also find opportunities to interact with decision makers (Carr and Hazell 2006). The benefit of this personal approach is the opportunity for information to flow in both directions and for site-specific recommendations to be made which allows for a more collaborative interaction and process (Carr and Hazell 2006; Rumps et al. 2007). We suggest that the development of any decision support tool should not be considered complete until there have been formal steps taken to provide the one-on-one interactions that will train the audience in the use of the tool.

The important and urgent conservation and management decisions we face today require interdisciplinary approaches to provide decision makers with the best available information (Pyke et al. 2007). Our results indicate that ecologists and conservation biologists should develop a wide variety of decision support tools and prioritize the oneon-one interactions between ecologists and decision makers that will enhance their delivery. Although there is a clear need for one-on-one interactions, this is also one of the costliest modes of information transfer. Government agencies and philanthropic foundations that provide financial support for developing information to support decisions should also support activities that will provide the one-on-one interactions to ensure that information is used effectively.

Acknowledgements We thank the respondents that took the time to complete the survey. T. Gardali, G. Geupel, and M. Pitkin helped to develop the questionnaire. Comments from J. Baker, G. Ballard, G. Geupel, J. Martin, and J. Wiens improved this manuscript. This work was supported by CALFED Science Fellowship U-04-SC-005 to N. E. Seavy. Portions of this manuscript were written at the Palomarin Field Station, which received support from NSF (DBI-0533918). This is PRBO contribution number 1701.

Open Access This article is distributed under the terms of the Creative Commons Attribution Noncommercial License which permits any noncommercial use, distribution, and reproduction in any medium, provided the original author(s) and source are credited.

\section{References}

Alexander JD, Seavy NE, Hosten P (2007) Using bird conservation plans to evaluate ecological effects of fuels reduction in southwest Oregon oak woodland and chaparral. For Ecol Manag 238:375-383

Alexander JD, Stephens JL, Geupel GR, Will TC (2009) Decision support tools: bridging the gap between science and management. In: Rich TD, Thompson CD, Demarest D, Arizmendi C (eds) Tundra to tropics: connecting birds, habitats, and people. Proceedings of the 4th international partners in flight conference. Partners in Flight, McAllen, Texas, pp 283-291

Berk RA (1983) An introduction to sample selection bias in sociological data. Am Sociol Rev 48:386-398

Bernhardt ES, Palmer MA, Allan JD, Alexander G, Barnas K, Brooks S, Carr J, Clayton S, Dahm C, Follstad-Shah J, Galat D, Gloss S, Goodwin P, Hart D, Hassett B, Jenkinson R, Katz S, Kondolf GM, Lake PS, Lave R, Meyer JL, O’Donnell TK, Pagano L, Powell B, Sudduth E (2005) Synthesizing US river restoration efforts. Science 308:636-637

Bernhardt ES, Sudduth EB, Palmer MA, Allan JD, Meyer JL, Alexander G, Follastad-Shah J, Hassett B, Jenkinson R, Lave R, Rumps J, Pagano L (2007) Restoring rivers one reach at a time: results from a survey of US river restoration practitioners. Restor Ecol 15:482-493 
Bonney R, Pashley DN, Cooper R, Niles L (eds) (1999) Strategies for bird conservation: the partners in flight planning process. Cornell Lab of Ornithology, Ithaca, New York

Carr A, Hazell D (2006) Talking frogs: the role of communication in ecological research on private land. Biodivers Conserv 15:3177-3191

Jenkinson RG, Barnas KA, Braatne JH, Bernhardt ES, Palmer MA, Allan JD, The National River Restoration Science Synthesis (2005) Stream restoration databases and case studies: a guide to information resources and their utility in advancing the science and practice of restoration. Restor Ecol 14:177-186

Katz SL, Barnas K, Hicks R, Cowen J, Jenkinson R (2007) Freshwater habitat restoration actions in the Pacific Northwest: a decade's investment in habitat improvement. Restor Ecol 15:494-505

Kondolf GM, Anderson S, Lave R, Pagano L, Merenlender A, Bernhardt ES (2007) Two decades of river restoration in California: what can we learn? Restor Ecol 15:516-523

O'Donnell TK, Galat DL (2008) Evaluating success criteria and project monitoring in river enhancement within an adaptive management framework. Environ Manag 41:90-105

Pullin AS, Knight TM (2001) Effectiveness in conservation practice: pointers from medicine and public health. Conserv Biol 15:50-54

Pullin AS, Knight TM (2005) Assessing conservation management's evidence base: a survey of management-plan compilers in the United Kingdom and Australia. Conserv Biol 19:1989-1996

Pullin AS, Stewart GB (2006) Guidelines for systematic review in conservation and environmental management. Conserv Biol 20:1647-1656

Pyke CR, Bierwagen BG, Furlow J, Gamble J, Johnson T, Julius S, West J (2007) A decision inventory approach for improving decision support for climate change impact assessment and adaption. Environ Sci Policy 10:610-621

Rauscher HM (1999) Ecosystem management decision support for federal forests in the United States: a review. For Ecol Manag 114:173-197

RHJV (2004) The riparian bird conservation plan: a strategy for reversing the decline of riparian associated birds in California. California Partners in Flight, Sacramento

Rumps JM, Katz SL, Barnas K, Morehead MD, Jenkinson R, Clayton SR, Goodwin P (2007) Stream restoration in the Pacific Northwest: analysis of interviews with project managers. Restor Ecol 15: 506-515

Salafsky N, Margoluis R, Redford KH, Robinson JG (2002) Improving the practice and conservation: a conceptual framework and research agenda for conservation science. Conserv Biol 16:1469-1479

Twedt DJ, Uihlein WB, Elliott AB (2006) A spatially explicit decision support model for restoration of forest bird habitat. Conserv Biol 20:100-110 